\title{
Changes in precipitation rates over the last 70 years in Eastern Paraná State, Brazil
}

\author{
Mudanças nas taxas de precipitação nos últimos 70 anos para o leste do \\ Paraná, Brasil
}

\section{Bruno Henrique Toná Juliani'®i), Cristhiane Michiko Passos Okawa"(i), Miriam Rita Moro Mine' ${ }^{10}$}

\author{
' Universidade Federal do Paraná, Curitiba, PR, Brasil \\ " Universidade Estadual de Maringá, Maringá, PR, Brasil
}

\section{ABSTRACT}

Temporal hydrometeorological series may present variations over time. The awareness of these characteristics is important to improve the monitoring of changes that these series may suffer along time. In this regard, the present paper aims to identify the existence of precipitation trends for the east portion of Paraná state, in Brazil, and also investigate the changes in the observed rates over the last 70 years. The statistical tests of Mann-Kendall and Pettitt, and also the Theil-Sen estimator, are applied for series of precipitation from 13 pluviometric stations of eastern Paraná state, Brazil, with 70 years of data records. By the results it was identified long-term linear positive trend for 11 of the precipitation series and also detected medium-term patterns in precipitation over 10 stations, characterizing the Joseph effect. These series have presented a behavior with higher rates in the most recent years in comparison from the first years of the historical data, sectioning the complete series into two shorter stationary periods, and presenting an abrupt change point.

Keywords: Hydrometeorological Series; Trends; Joseph Effect

\section{RESUMO}

Séries temporais hidrometeorológicas podem apresentar variações ao longo dos anos. O conhecimento dessas características é importante para um melhor monitoramento de mudanças nestas séries ao longo do tempo. Neste contexto, o presente artigo tem por objetivo identificar a existência de tendência na precipitação da porção leste do estado do Paraná, Brasil, e investigar as mudanças nos registros observados dos últimos 70 anos. Os testes de Mann-Kendall e de Pettitt, bem como o estimador de TheilSen, foram aplicados em séries de precipitação de 13 estações pluviométricas localizadas na região leste do estado do Paraná, com registros de 70 anos de dados. Pelos resultados observados, foram identificadas tendências lineares positivas de longo termo para 11 das séries de precipitação, e também detectados padrões de médio termo na precipitação de 10 estações, caracterizando o Efeito José. Essas séries apresentaram comportamento com taxas mais altas de precipitação nos anos mais recentes, em 
comparação aos primeiros anos da série histórica, dividindo a série completa em dois períodos menores com comportamento estacionário, e apresentando um ponto de mudança abrupto.

Palavras-chave: Séries hidrometeorológicas; Tendências; Efeito José

\section{INTRODUCTION}

Temporal hydrometeorological series are consisted by rates of variables such as precipitation and flow, in observations and measurements on a regular time scale. Naghettini and Pinto (2007) discuss that these series may have characteristics of stationarity and non-stationarity. The series with statistical characteristics unchangeable over time are called stationary series, while those with the presence of trends or abrupt shifts, which consequently affect the statistical patterns, are classified as non-stationary series. The non-stationarity may be resulted by natural variations in climate and also by human activities.

It is important to identify the stationarity behavior of the hydrological series not only to relate to the past, but also to comprehend its evolution in present and in the future. Furthermore, many techniques in statistical hydrology take as assumption the stationarity and homogeneity of the series (NAGHETTINI; PINTO, 2007). However, the identification of the trend is subjected to the data variability, the trend magnitude, the statistical significance level and also to the length of the data series (STAHL et al., 2010).

When analyzing the variability in precipitation, it is important to evaluate the existing differences in the phenomenon's behavior, as precipitation is not only temporal but also spatially variable. Mello and Sampaio (2019) state the average annual precipitation for Paraná state, Brazil, as $1682.7 \mathrm{~mm}$, with usually dry winters and humid summers. Siqueira, Nery and Martins (2018) evaluate this variability, and concluded that the state is not influenced by intra-annual large oscillations, constituting an area with greater regularity in rainfall patterns.

Worldwide many researchers have applied statistical tests such as Mann-Kendall and Pettitt in order to identify trends. Yang et al. (2018) studied flow and rainfall in China, analyzing series of 47 years length, from 1959 to 2005. Hajani and Rahman (2018) 
investigated the characteristics of precipitation in Australia from 1945 to 2014, a 70 year-length. Kazemzadeh and Malekian (2018) covered hydroclimatic changes in Iran for 30 years, from 1981 to 2010. Moreover, recent studies in Canada (TAN et al., 2017), Germany (BORMANN; PINTER, 2017), India (PIYOOSH; GHOSH, 2017) and United States (TEEGAVARAPU; NAYAK, 2017) can also be listed. The common ground of these studies is the availability of long time records for the hydrological information.

Studies of trends in Brazil have also been published. Penereiro and Orlando (2013) analyzed climatic and hydrologic data of Northeast region. Uliana et al. (2015) applied statistical tests in precipitation and flow data of stations in Espírito Santo. Santos et al. (2016) also studied precipitation and flow trends for the Southeast region. Zandonadi et al. (2015) investigated trends and patterns of the precipitation of Paraná river basin. Quadros et al. (2018) analyzed variability and precipitation trends of Paraná state.

Obregón and Marengo (2007) evaluate trends in precipitation for the whole Brazil, and pointed significative increase in total annual precipitation in the second half of the twentieth century for almost all South Region of Brazil. Evaluating sub-basins of the Southeast portion of the Brazilian Atlantic basin, Melati and Marcuzzo (2016) try to find a correlation between trends in precipitation and the elevation of the stations, but a clear conclusion was not stated.

In the XXIII Brazilian Symposium on Water Resources, 2019, some papers regarding trends and changes in hydrological variables across Brazil were presented. With a specific focus on precipitation trends, it can be highlighted the studies of Chagas and Chaffe (2019), Lima et al. (2019) and Juliani et al. (2019). Although similar methodologies were applied, the studies diverge mainly in the length of the series applied, as there is no consensus regarding the real influence of the sample size in trend results.

Thus, this present paper aims to identify the existence of precipitation trends for Paraná state, in Brazil, and also investigate the changes in the observed rates over the last 70 years. In this regard, the statistical non-parametric test of Mann-Kendall and Theil-Sen estimator are applied for the linear trend evaluation, and the Pettitt test is applied for identification of an abrupt change point. 


\section{MATERIAL AND METHODS}

Meteorological dataset were obtained from the Hydrological Information System of Paraná Water Institute (AGUASPARANA, 2020). The selection of the pluviometric stations considered the data availability, with a time record of 70 years of monthly values without missing values. Considering this, 13 stations were selected for Paraná State, as shown in Figure 1 and described in Table 1. The geographic information of the stations is provided by the National Water Agency (2021), in the Brazilian National Information System on Water Resources (SNIRH) website.

Figure 1 - Pluviometric stations selected for the study

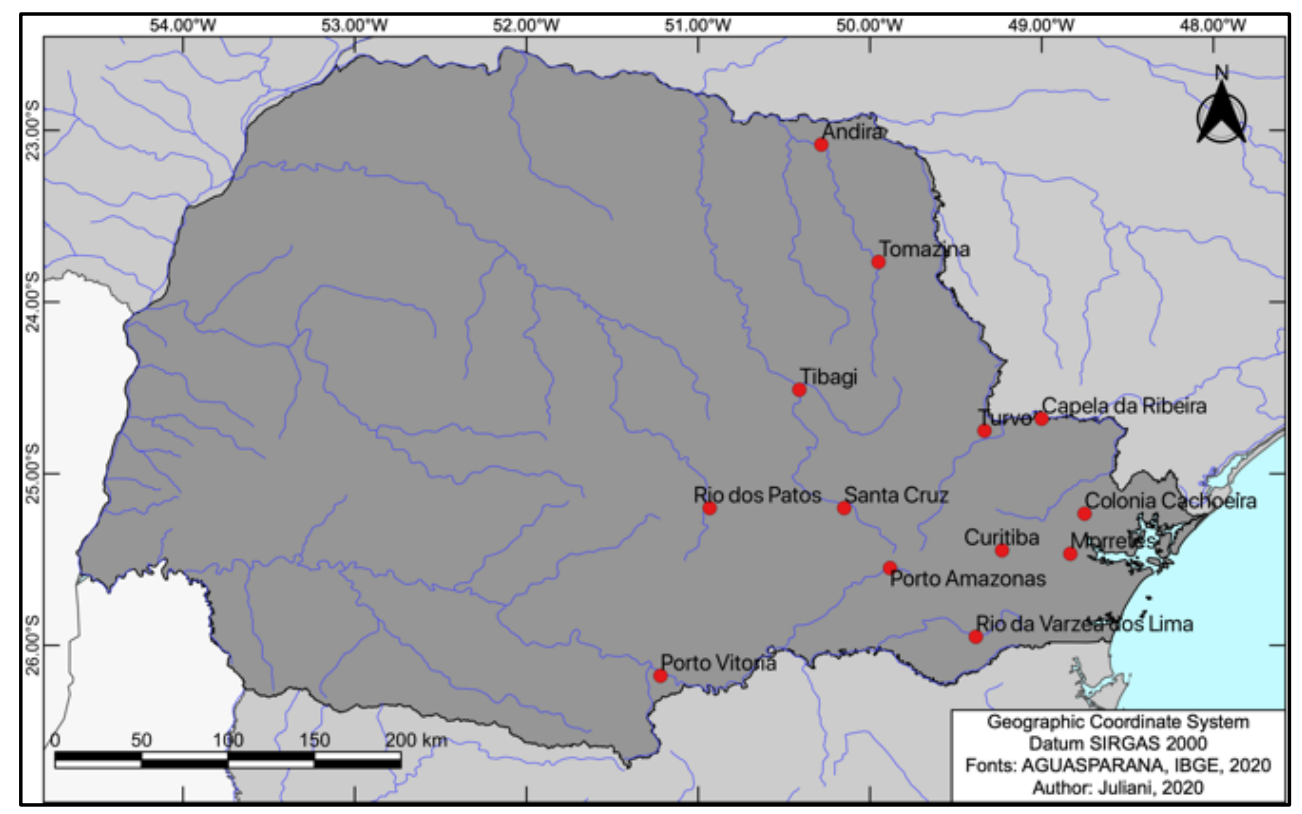

Fonte: autores (2021)

From Figure 1 it can be observed that the stations which matched the requirements of 70 years of monthly values are not well distributed along the whole Paraná, being located in the eastern portion of the state. Thus, a spatial study case along the state can not be performed due to the lack of data, and a more regional approach was selected, studying the east of Paraná. The study area presents average annual precipitation rates varying from $1400 \mathrm{~mm}$ to $2100 \mathrm{~mm}$. The higher rates are concentrated at the coastline, while most of the area ranges from $1400 \mathrm{~mm}$ to $1600 \mathrm{~mm}$, as reported in the Brazilian Pluviometric Atlas (PINTO et al., 2011). Table 1 also lists the average annual precipitation for each of the studied stations. 
Table 1 - Geographic information and average annual precipitation for selected pluviometric stations

\begin{tabular}{lccccc}
\hline \multicolumn{1}{c}{ Station } & SNIHR Code & Latitude $\left(^{\circ}\right)$ & Longitude $\left(^{\circ}\right)$ & Elevation(m) & Precipitation (mm/yr) \\
\hline Andirá & 2350002 & -23.0853 & -50.2856 & 375 & 1300.7 \\
Capela da Ribeira & 2449000 & -24.6556 & -48.9997 & 180 & 1128.1 \\
Colônia Cachoeira & 2548003 & -25.2333 & -48.7500 & 80 & 2533.3 \\
Curitiba & 2549006 & -25.4333 & -49.2667 & 924 & 1490.2 \\
Morretes & 2548000 & -25.4667 & -48.8333 & 8 & 2073.21 \\
Porto Amazonas & 2549001 & -25.5500 & -49.8833 & 793 & 1475.1 \\
Porto Vitória & 2651004 & -26.1667 & -51.2167 & 790 & 1754.1 \\
Rio da Várzea dos Lima & 2549003 & -25.9500 & -49.3931 & 810 & 1485.5 \\
Rio dos Patos & 2550000 & -25.2372 & -50.9608 & 690 & 1617.1 \\
Santa Cruz & 2550003 & -25.1333 & -50.1500 & 790 & 1572.0 \\
Tibagi & 2450002 & -25.5108 & -50.4000 & 720 & 1573.4 \\
Tomazina & 2349033 & -23.7667 & -49.9500 & 483 & 1428.6 \\
Turvo & 2449007 & -24.7500 & -49.3333 & 400 & 1269.1 \\
\hline
\end{tabular}

Fonte: autores (2021)

The average annual precipitation for the stations presented in Table 1 is within the expected from the Brazilian Pluviometric Atlas (PINTO et al., 2011). It draws attention to station Colônia Cachoeira, with an average annual precipitation of $2533.3 \mathrm{~mm}$. It is explained by the location of the station in mountainous terrain and the high incidence of orographic rainfall in these conditions.

From the obtained dataset provided, annual precipitation series were taken in consideration for each of the selected stations. For comparison reasons, the dataset for all stations was the precipitation time series from 1950 to 2019 . Based on the annual series, the statistical non-parametric test of Mann-Kendall and Theil-Sen estimator were applied, as follows. For comparison reasons, from the complete series, moving sub-sets with 30, 40, 50, 60 and 70 years were taken from each of the stations. By this, it is expected to observe the behavior of the time series of different sizes over different periods. The adopted starting points for the series were the years terminating in zero, therefore the years 1950, 1960, 1970, 1980 and 1990, and the endpoint years ending in nine, considering the different lengths and with the last year of study being 2019.

For further investigation of different trend patterns along the whole time series, the Pettitt test was used to identify the year of the most significative shift of trend, leading to a division of two sub-series. 


\subsection{Mann-Kendall Test}

The Mann-Kendall test was initially conceived by Mann (1945) as a non-parametric test for the detection of monotonic trends, and complemented by Kendall (1975) with a statistical distribution for the test aiming to identify also non-linear variations and inflexion points. According to Tan et al. (2017), the test is being vastly recommended for the identification of significative statistical trends for time series of hydroclimatic variables, as a robust test for data in which may be presented outliers and non-linear trends.

The null hypothesis of the test indicates an independent series with randomly distributed variables, without the presence of a trend. On the other hand, the alternative hypothesis represents a series with positive or negative monotonic trend. The test statistics are computed as follows.

$$
\begin{aligned}
& S=\sum_{k=1}^{n-1} \sum_{j=k+1}^{n} \operatorname{sgn}\left(x_{j}-x_{k}\right) \\
& \operatorname{sgn}\left(x_{j}-x_{k}\right)=\left\{\begin{array}{cll}
1, & \text { for } & x_{j}-x_{k}>0 \\
0, & \text { for } & x_{j}-x_{k}=0 \\
-1, & \text { for } & x_{j}-x_{k}<0
\end{array}\right. \\
& Z(M K)=\left\{\begin{array}{cll}
\frac{S-1}{\sqrt{\operatorname{var}(S)},} & \text { for } & S>0 \\
0, & \text { for } & S=0 \\
\frac{S+1}{\sqrt{\operatorname{var}(S)},} & \text { for } & S<0
\end{array}\right.
\end{aligned}
$$

The Mann-Kendall test may be evaluated by its statistic $Z$. For positive values, an ascending trend is identified, while negative values indicate the presence of a descendent trend. In a significance level of 5\%, it fails to reject the null hypothesis in the range $-1.96<Z<1.96$.

\subsection{Theil-Sen Estimator}

Initially proposed by Theil (1950) and further explored by Sen (1968), the Theil-Sen Estimator computes the slope and magnitude of the trend using non-parametric statistics. Byakatonda et al. (2018) state that the estimator is usually used in a 
combination with the Mann-Kendall test, for a better understanding of the results. The estimation of the trend is computed as follows.

$$
Q_{i}=\frac{x_{j}-x_{k}}{j-k}
$$

The $Q_{i}$ represents the estimator for two points of the data, and is computed for the whole set of two data points of the series, with $j>k$. The Theil-Sen estimator of the data series is the median measure of $Q$.

\subsection{Pettitt Test}

The Pettitt test (PETTITT, 1979) is based in the division of the sample in two different parts, testing statistical tendencies for both parts and comparing them. Thus, the test identifies significative statistical points in which a shift in the trend is noticed. Tan et al. (2017) state that this test is also vastly used in hydroclimatic series, as it is robust to outliers and applicable to data of different probability distributions.

The test considers a series with $N$ values, grouping them into two subsamples represented by $\left(x_{1}, \ldots, x_{t}\right)$ and $\left(x_{t+1}, \ldots, x_{N}\right)$. The test is established as it follows.

$$
\begin{gathered}
U_{t, N}=U_{t-1, N}+\sum_{j}^{N} \operatorname{sgn}\left(X_{t}-X_{j}\right), \quad(t=2, \cdots, N) \\
\operatorname{sgn}\left(X_{t}-X_{j}\right)=\left\{\begin{array}{ccc}
1, & \text { for } & X_{t}-X_{j}>0 \\
0, & \text { for } & X_{t}-X_{j}=0 \\
-1, & \text { for } & X_{t}-X_{j}<0
\end{array}\right.
\end{gathered}
$$

The test statistic counts the number of times in which the value of the first subsample exceeds the value of the second one, as stated in equation 6 . This statistic represents the significative shifting point $t$, associated to a significance level. The trends statistics of this study are carried at a significance level of $5 \%$. 


\subsection{Trend identification}

The non-parametric statistical test of Mann-Kendall was applied to the identification of linear trends in the different duration series for all the 13 selected stations. The purpose of the application of the test for all of the segments in the same series is to verify if the length and temporal position of the series affects the results of the trend identification, and also to provide a better understanding in the series behavior over time.

Complementing the analysis, the Pettitt test was applied in order the detect the year of the most significative shift in the series. By the division of the original series into two sub-sets, the Mann-Kendall test and the Theil-Sen estimator were then applied in these two new series for a more accurate analysis.

\section{RESULTS AND DISCUSSIONS}

Applied the described methodology for the Mann-Kendall test and Theil-Sen estimator in the complete time series, 11 of the 13 studied stations presented the existence of a positive trend in precipitation according to the Mann-Kendall test at a 5\% significance level. The exceptions were the stations Curitiba and Porto Vitória, that did not present statistically significative trend. The p-values and Sen's slopes for all studied stations are listed in Table 2.

By the analysis of the whole historic record of precipitation, the annual precipitation time series for Curitiba and Porto Vitória are said to be stationary in the period analyzed, based on the Mann-Kendall test. For the stations with a result in the Mann-Kendall test with a p-value smaller than 0.05 it is said that the null hypothesis of the test was reject in a 5\% significance level. So, based on this test, these time records may be taken as non-stationaries, with their specific statistics varying over time. This is an important result at the series analysis, as many applications and projections of time series admit a stationary series, and if this effect is not considered, possible flaws and errors in practices in the water management and projects may occur. 
Table 2 - Mann-Kendall test applied to 70-year annual precipitation series of selected stations

\begin{tabular}{lcc}
\hline \multicolumn{1}{c}{ Station } & p-value & Sen's slope \\
\hline Andirá & 0.0377 & 3.7775 \\
Capela da Ribeira & 0.0086 & 4.7707 \\
Colônia Cachoeira & 0.0000 & 11.0167 \\
Curitiba & 0.1679 & 2.2000 \\
Morretes & 0.0001 & 8.5962 \\
Porto Amazonas & 0.0001 & 6.5524 \\
Porto Vitória & 0.1361 & 3.2596 \\
Rio da Várzea dos Lima & 0.0062 & 4.6532 \\
Rio dos Patos & 0.0010 & 6.4200 \\
Santa Cruz & 0.0094 & 5.8955 \\
Tibagi & 0.0222 & 4.2680 \\
Tomazina & 0.0163 & 4.1179 \\
Turvo & 0.0000 & 11.5207 \\
\hline
\end{tabular}

Fonte: autores (2021)

For a more detailed evaluation of the presence of trends over the last 70 years of records for these stations, sub-sets of 30,40, 50 and 60 years were studied separately.

When analyzing the results of the station Andirá, it can be noted that no trend was identified in series with 30 years. In the series of 40 years, a significative trend was identified for the period 1960 - 1999, while for the 50-year series, trends were identified in two periods: from 1950 to 1999; and from 1960 to 2009. For the 60-year series, positive trends were identified in both periods. The common period between these different results in the identification of trends is from 1960 to 1999, when possibly the transformation in the patterns of precipitation was more intense. However, it should be pointed that changes over 30 years were not considered significative at a 5\% significance level, and for these stations a non-stationary process was identified only when considering 40 years of records.

In Capela da Ribeira, only the series from 1960 to 1989 indicated changing patterns from the 30-year series, demonstrated by an increase in precipitation rates in this period. When analyzing the 40 years length series, a trend was identified for the period from 1970 to 2009. This evidence the influence of the length of the series for the identification of trends, since this second period, when analyzing from two moving 30-year series did not presented a trend. For the 50-year long series, trends were identified in the series starting in 1960 and 1970, and when analyzing 60 consecutive years only the series from 
1960 to 1999 presented a significative trend. For the cases where no trend was identified, the series still present a variation in its rates, intercalating periods of lower and higher indices, and thus, not considered as a trend. The identification of the different periods and trends for station Capela da Ribeira can be visualized in Figure 2.

Figure 2 - Trend analysis over different periods for station Capela da Ribeira

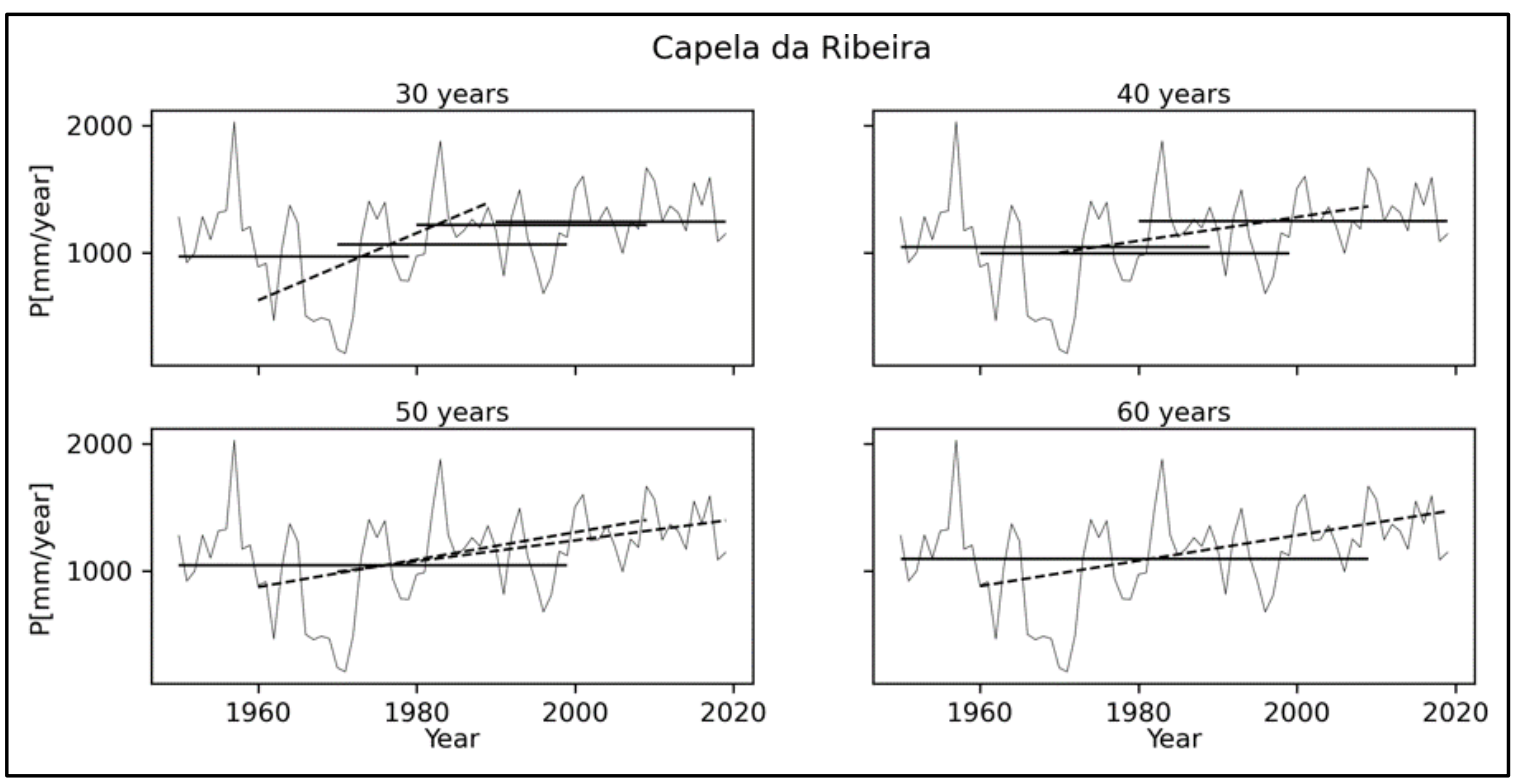

Fonte: autores (2021)

In Colônia Cachoeira two of the 30-year length series were identified with trends: from 1970 to 2000; and from 1990 to 2019. For the series with 40 years, trends were identified in the series starting in 1960, 1970 and 1980. Trends were also identified for all longer series. By this, it can be said that no trends were presenting in the series in the first years of record, and that a similar occurrence for the 30-year trend identification from Capela do Ribeiro occur in this station.

For the station Morretes, when analyzing the 30-year series, only the sub-set from 1970 to 1999 registered a significative trend at 5\% significance level. When considering series of 40 years, a trend was identified for the series starting in 1960, and for the 50 years long series, the Mann-Kendall test resulted in significative trends for the series starting in 1950 and 1960. Trends were also present in the longer series of 60 and 70 years. Here, it can be said that the period from 1970 to 1999 presented a significative increase in precipitation rates, with a predecessor and a successor periods with more constant rates. 
The precipitation record of the station Porto Amazonas has presented significative trends for all sub-sets of 60 and 50 years. As to the 40 -years sub-sets, the only period with a trend identified was from 1960 to 1999.

Porto Vitória, a station where no trend was identified when considered the whole time series, presented a significative trend when analyzing the period from 1950 until 1999 (50 years). Here, the values from the 1980 decade are similar to the ones of the first years of record, however in the 50-year analysis, the influence of higher rates of precipitation in the subsequent decade makes the identification of the trend for this whole period once again significative at a $5 \%$ significance level.

Rio da Várzea had no trend identified in a 30-year basis, and for a 40-year analysis, a positive trend was identified from 1960 to 1999. For the series of 50 years, only the series starting in 1960 was classified with a non-stationary characteristic. As for the series of 60 years, the Mann-Kendall test indicated a trend only for the first of the series. By these results and by the visual analysis of the time series, it can be noted that a group of years with smaller rates in the decade of 1960 affected the trend results for the different tested periods, as demonstrated in Figure 3.

Figure 3 - Trend analysis over different periods for station Rio da Várzea

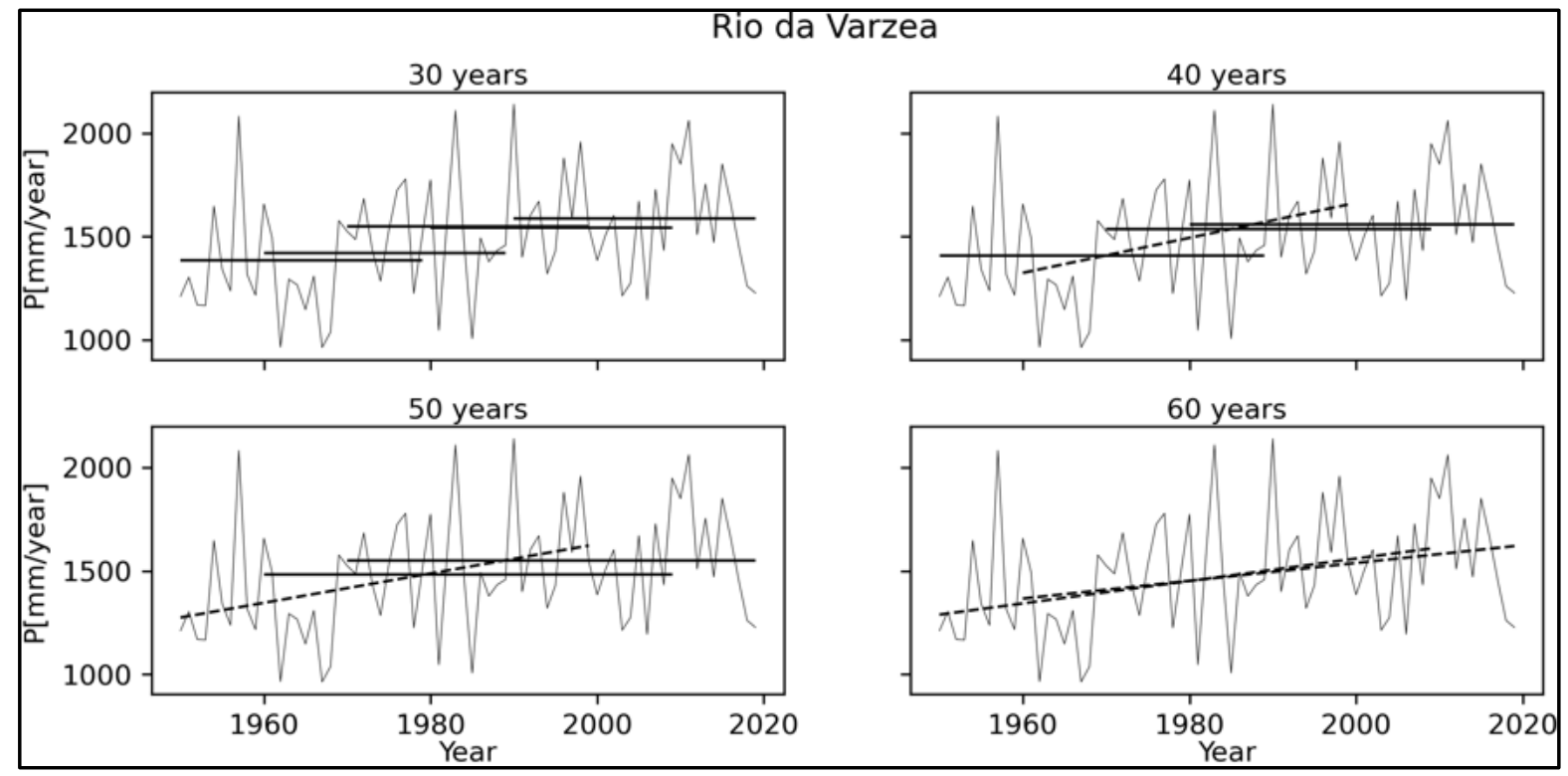

Fonte: autores (2021) 
Regarding to the station Rio dos Patos, positive trends were identified by the MannKendall test at a 5\% significance level for both series 60 years, and also for the 50 -year series from 1950 to 1999 and from 1960 to 2019. For the 40-year segments, the trends were identified in the series from 1960 to 1999 and from 1970 to 2009, while for the 30-year segments, only from 1970 to 1999 a positive trend was indicated. By this, it can be inferred that the shifts occurred in the middle of the analyzed time series, as no minor series with 30 or 40 years identified trends when considering the years from 1950 to 1960 and from 2010 to 2019. Analyzing the annual precipitation series, a group of years with higher rates can be observed in the decade of 1990, leading to the positive trend identification for the series with these years as the final years of record, as observed in Figure 4.

Figure 4 - Trend analysis over different periods for station Rio dos Patos

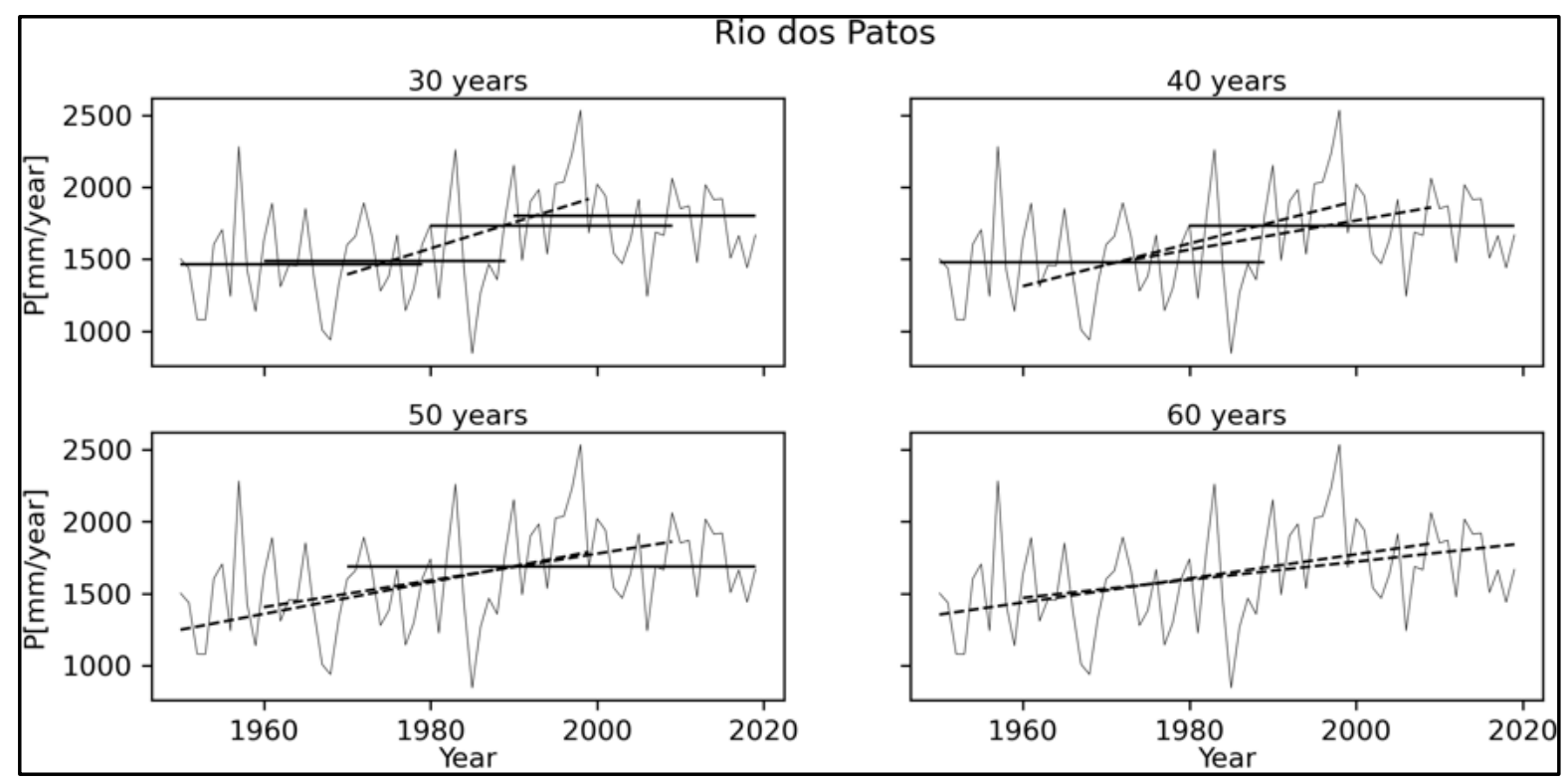

Fonte: autores (2021)

For the series generated for the station Santa Cruz, two positive trends were indicated by the results of the Mann-Kendall test at a 5\% significance level. Besides the mentioned trend for the whole series, considering the 70-year period, when considering 60 consecutive years, the series starting in 1960 until 2019 also indicated a linear trend.

Among the pluviometric sub-series for station Tibagi, the Mann-Kendall test pointed to positive trends at a $5 \%$ significance level in all of the series starting in the year of 1950, with lengths of 30,40, 50 and 60 years. Therefore, it can be said that the 
most significative shift in the rates of precipitation occurred in the first years of the record, and then the rates have become more uniform.

Similar to the case of station Tibagi, the trends identified for the series of station Tomazina also were presented in the series of the first years of the record. For this station, no trend was identified in the 30-year sub-sets of data, and for the other ranges of years, the trends were noted in the series starting in the years of 1950 and 1960. Thus, for the 40-year records, the Mann-Kendall test identified positive trends for the series from 1960 to 1999. Also, for the 50-year records, a trend was pointed in the period from 1950 to 1999, while for the 60-year records a trend was identified when analyzed the years from 1950 to 2009.

Lastly, for the station Turvo all selected sub-sets of data with more than 50 years were identified as non-stationary periods according to Mann-Kendall test at a 5\% significance level. Regarding the 40-year periods, trends were identified in the series from 1950 to 1989 , from 1960 to 1999 and from 1970 to 2009, while for the 30-year periods, the sub-sets with positive trends were from 1960 to 1989 and from 1970 to 1999. It can be then inferred that the years with the most significative change in the rates were the years from 1960 to 1999. This is illustrated in Figure 5.

Figure 5 - Trend analysis over different periods for station Turvo

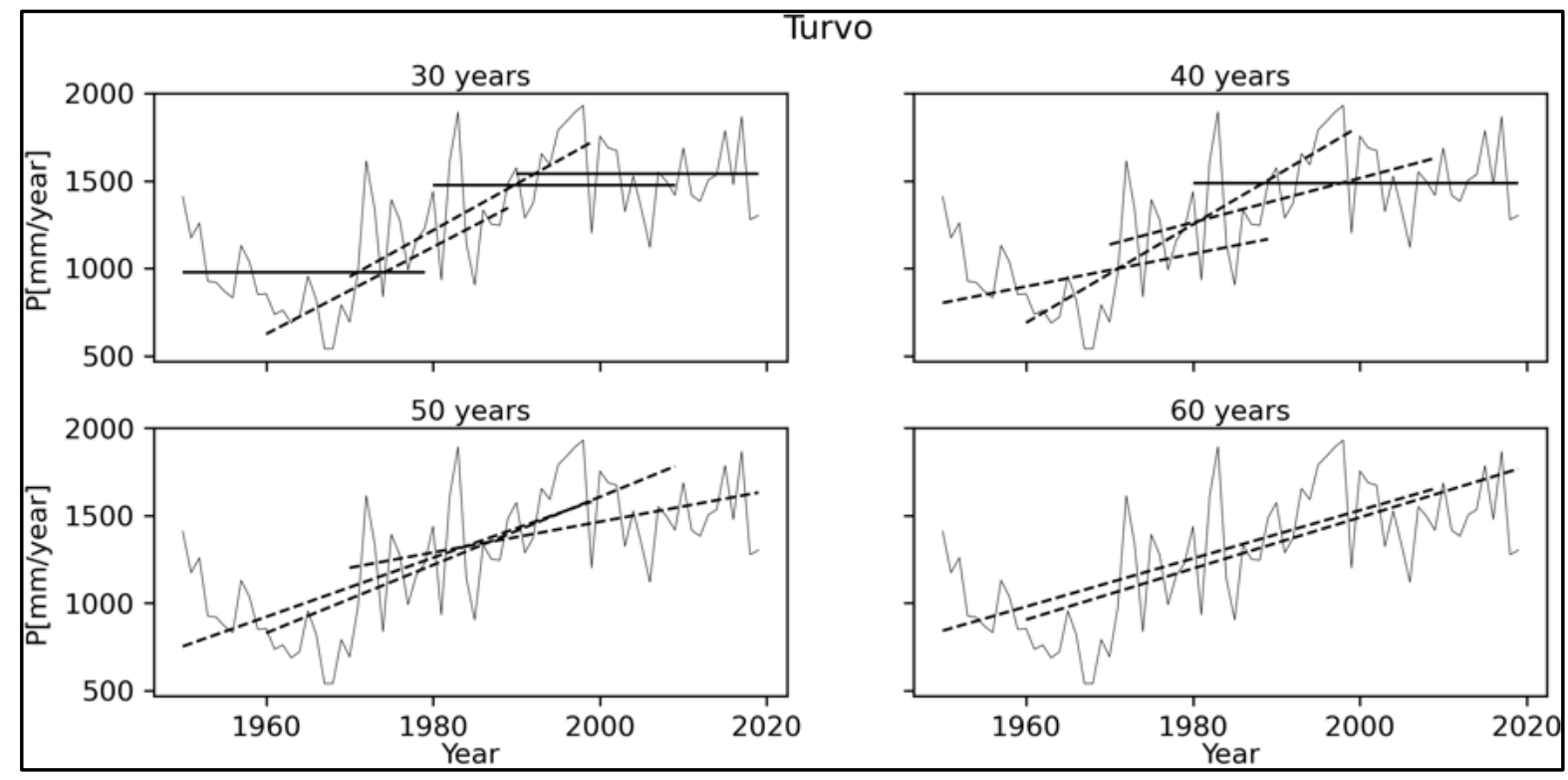

Fonte: autores (2021) 
By the difference noticed between the results of Mann-Kendall test for the different series durations, it is evidenced that the indices of trends identified by this method do not represent the behavior of the whole series, but only the behavior for the analyzed period. The test applied to longer periods may indicate the long-term evolution of the precipitation rates, however may conduct to false conclusions. Analyzing shorter periods may lead the better results in the identification of the most recent evolution of the climatological variable, however the results for these shorter periods can not be extended over much longer periods of time.

As observed by the results of the Mann-Kendall test, shorter series are less likely to present trends in a 5\% significance level, contrary to the longer ones. This may evidence the existence of periods in which the characteristics and statistics are more compatible, forming blocks over the time series. These events of a lower duration may be a characteristic of climate variability, as a natural variation from one period to another. The looping succession over dry and wet periods is called Joseph effect, as recurring patterns (MANDELBROT; WALLIS, 1968). Zuffo (2015) attested the occurrence of a dryer period in Campinas, state of Sao Paulo, from the years 1933 to 1970 as a cyclical effect. The author conclusions supplement the findings of this article, as shorter series are not representative in demonstrating the long-term evolution of an entire hydrological aspect.

Extending the study of the shifts in precipitation rates over the time series registered, the Pettitt test was applied aiming to identify possible points of discontinuity in the longer series, in a division of two more homogenous sub-series, as possible division points of the Joseph effect. For this analysis, the 70-year duration series of annual precipitation for the selected stations were applied. The results of the test were evaluated at a $5 \%$ significance level, and for three of the 13 series the test did not indicate the existence of a change point. The result from the Pettitt test for the series of the stations Curitiba, Porto Vitória and Santa Cruz were not conclusive for the adopted significance. For the series which the Pettitt test indicated the existence of a year of change, the results are shown in Table 3. 
Table 3 - Change points according to Pettitt test results

\begin{tabular}{lcc}
\hline \multicolumn{1}{c}{ Station } & p-value & Year of shift \\
\hline Andirá & 0.0415 & 1985 \\
Capela da Ribeira & 0.0113 & 1981 \\
Colônia Cachoeira & 0.0000 & 1992 \\
Morretes & 0.0003 & 1979 \\
Porto Amazonas & 0.0010 & 1981 \\
Rio da Várzea dos Lima & 0.0119 & 1968 \\
Rio dos Patos & 0.0002 & 1988 \\
Tibagi & 0.0018 & 1971 \\
Tomazina & 0.0157 & 1971 \\
Turvo & 0.0000 & 1981 \\
\hline
\end{tabular}

Fonte: autores (2021)

As observed in Table 3, the years of occurrence of the shifts varied from 1968 to 1992. Therefore, it can be said that the hydrological changes in patterns of precipitation for these series are not concentrated in the same period in time, with a specific time of occurrence for each station, without the identification of a pattern.

Another point for consideration is that this test is indicated for longer series, as the length for sub-series should be sufficient to validate its own statistics. Observing the years of shift in the results of the series from 1950 to 2019, the earlier identification was for the station Rio da Várzea dos Lima, in 1968, and the most recent for Colônia Cachoeira, in 1992, with the minor sub-series with durations of 18 and 29 years, respectively. Hajani and Rahman (2018) explain that the direction of the abrupt shift by Pettitt test is determined by the comparison of the predecessor and successor subseries related to the change point.

For all the studied stations the shorter series did not present a valid trend in a 5\% significance level by Mann-Kendall test. Thus, it can be said that the Pettitt test divided the complete data record into two stationary series with an abrupt change point. With this characteristic, it can be said that the Joseph effect is present in the 10 stations with a significative Pettitt test result. The visualization of this phenomenon for two of these stations is illustrated in Figure 6. The first one is the station Tibagi, with an increase of $24 \%$ in the average annual precipitation, from $1350 \mathrm{~mm}$ to $1670 \mathrm{~mm}$. The series of station Morretes registered the occurrence of the abrupt change in the year 1979, with the average annual precipitation varying from $1855 \mathrm{~mm}$ to $2228 \mathrm{~mm}$, a $20 \%$ increase. 
Figure 6 - Division of pluviometric time series for stations Tibagi and Morretes

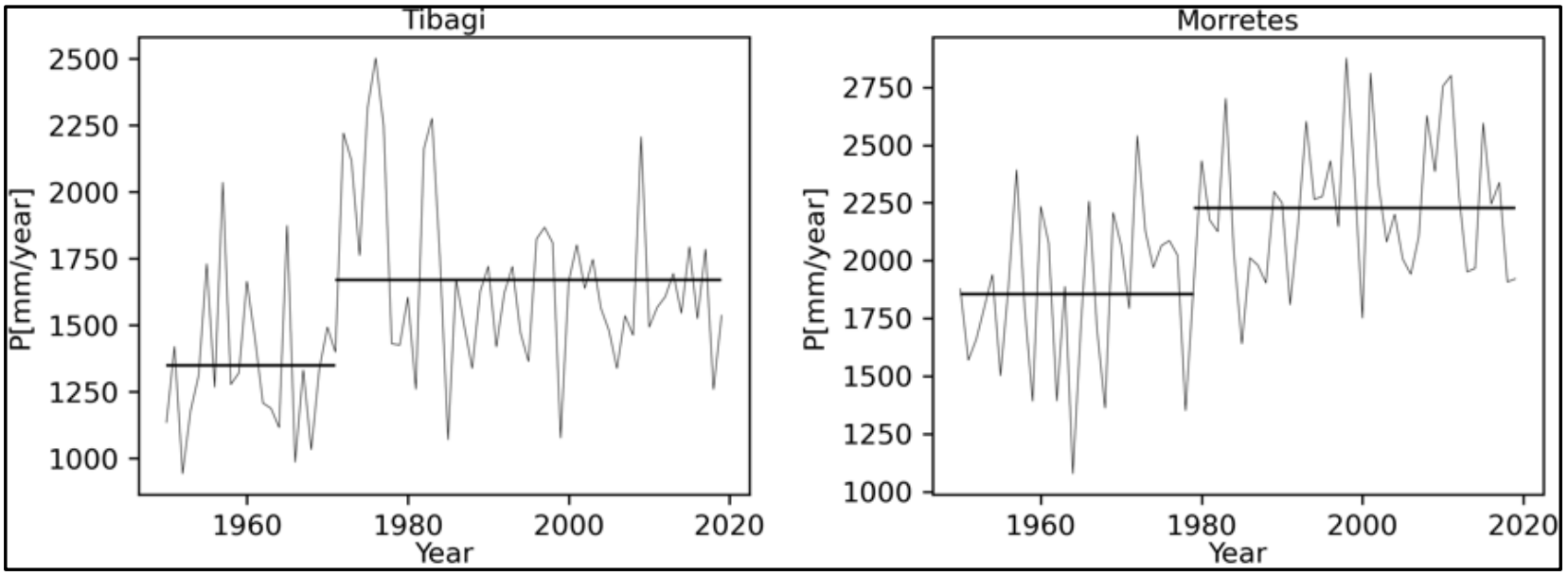

Fonte: autores (2021)

It should be highlighted that the Pettitt test identifies only one abrupt change point in the historical data series. Therefore, two more consistently patterned periods were identified. Larger time series may present even a larger number of blocks with more similar characteristics. This way, for a complete understanding regarding the presence and evolution of the Joseph effect, other techniques in the detection of the shifts should be applied. As longer records provides a larger number of data for the analysis, the continuous study of the pluviometric time series is important to improve the knowledge regarding its characteristics.

Some other studies also investigated precipitation trends for Paraná state. Zandonadi et al. (2015) stated an increase in annual precipitation for the east part of Paraná river basin, when analyzing the period from 1986 to 2011, with data obtained from the National Institute of Meteorology. The time series of Zandonadi et al. (2015) work is similar to the second period of time identified by the Pettitt test in this paper, and in this case, no trends were identified. These different results may be due to the different fonts of data, and also by the difference in the number of years for the statistical tests.

The study of Quadros et al. (2018) applied trend tests into projections of series from the National Water Agency. The original series had 30 years of time record and, by predictions, were expanded into series of 70 years. In these new series, increasing trends were identified, which corroborate with the results of this paper.

It is important to emphasize that the occurrence of these changes is not limited to the period of records, as the hydroclimatologic phenomena are not limited to the length 
of the time series. The changes appointed in this paper are linked to the periods of study, and as explained, have different results for different lengths of series.

\section{CONCLUSIONS}

With the results provided by the tests and analysis carried out, the first point to highlight is the existence of a long-term trend for 11 of the 13 complete pluviometric series analyzed, according to results obtained by the Mann-Kendall test in a $5 \%$ significance level. So, it can be said that the precipitation behavior on these locations is non-stationary when the previous 70 years is considered, and that the rates are increasing in a long-term scale.

The results of the Pettitt test identified a change point for 10 of the 13 studied precipitation series, with occurrences from 1968 to 1992, without a pattern covering all stations. As observed, the rates in these 10 stations have increased significantly in the most recent period, which confirm the results obtained by the linear trend tests.

From the division of the whole record into two sub-series for 10 of the series, it was possible to visualize two stationary patterns. This fact evidences the occurrence of the Joseph effect for these stations, which would be even better demonstrated with a bigger time series and with a method for the identification of more than one abrupt shift in the series.

In attempt to find a correlation between the average annual precipitation and the increase rate, the stations were classified from the one with the highest rate to the lowest: Colônia Cachoeira, Morretes, Porto Vitória, Rio dos Patos, Tibagi, Santa Cruz, Curitiba, Rio da Várzea dos Lima, Porto Amazonas, Tomazina, Andirá, Turvo and Capela do Ribeira. The stations were also classified according to the increase between the two periods identified by the Pettitt test, from the highest rate of increase to the lowest: Turvo, Capela do Ribeira, Rio dos Patos, Colônia Cachoeira, Morretes, Porto Amazonas, Rio da Várzea dos Lima, Tomazina and Andirá. Although the two stations with the highest increases are the two with the lowest long-term average annual precipitation, this relation can not be proved as the correlation is not sustained.

The major limitation of this study was the small number of pluviometric stations with longer time series with consistent data in the area of the Paraná state. Thus, these results are restricted to a limited area. The methodology can be applied in other regions of the country and also worldwide, where a larger number of stations with the selected 
characteristics are possibly found. These results may be compared for evaluation of spatial patterns among regions.

As recommendation for future studies is the identification of minor divisions in the hydrological time records for more specific patterns. With the continuous monitoring of rainfall records in pluviometric stations, in future years it will be possible to expand and compare the results not only for the stations listed in this paper, but also for others that reach the required amount of data.

\section{REFERENCES}

AGUASPARANA. Hydrological Information System of Parana's Water Institute. 2020. Disponível em: http://www.aguasparana.pr.gov.br. Acesso em 5 mai. 2020.

BORMANN, H.; PINTER, N. Trends in low flows of German rivers since 1950: Comparability of different low-flow indicators and their spatial patterns. River Research and Applications, v. 33, n. 7, p. 1191-1204, 2017.

BYAKATONDA, J. et al. Analysis of long term drought severity characteristics and trends across semiarid Botswana using two drought indices. Atmospheric Research, v. 213, p. 492-508, 2018.

CHAGAS, V. B. P.; CHAFFE, P. L. B. Análise das tendências de chuva no Brasil, de 1980 a 2015. In: Simpósio Brasileiro de Recursos Hídricos, 23, 2019, Foz do Iguaçu. Anais. Foz do Iguaçu: ABRHidro, 2019.

HAJANI, E.; RAHMAN, A. Characterizing changes in rainfall: A case study for New South Wales, Australia. International Journal of Climatology, v. 38, n. 3, p. 1452-1462, 2018.

JULIANI, B. H. T. et al. Estudo de estacionariedade na série histórica de precipitação da estação Tibagi, Paraná. In: Simpósio Brasileiro de Recursos Hídricos, 23, 2019, Foz do Iguaçu. Anais... Foz do Iguaçu: ABRHidro, 2019.

KAZEMZADEH, M.; MALEKIAN, A. Changeability evaluation of hydro-climate variables in Western Caspian Sea region, Iran. Environmental Earth Sciences, v. 77, n. 120, p. 12, 2018.

MANN, H. B. Nonparametric Tests Against Trend. Econometrica, v. 13, n. 3, p. 245-259, 1945.

MELATI, M. D.; MARCUZZO, F. F. N. Efeito da altitude na chuva média anual nas sub-bacias pertencentes à bacia do Atlântico - trecho sudeste. In: Simpósio de Recursos Hídricos do Nordeste, 13, 2016, Aracaju. Anais... Aracaju: ABRHidro, 2016.

LIMA, S. G. et al. Análise de tendência em precipitações no sertão alagoano: estudo de caso do município de Delmiro Gouveia. In: Simpósio Brasileiro de Recursos Hídricos, 23, 2019, Foz do Iguaçu. Anais... Foz do Iguaçu: ABRHidro, 2019.

MELLO, Y. R.; SAMPAIO, T. V. M. Análise geoestatística da precipitação média para o estado do Paraná. Revista Brasileira de Climatologia, v. 25, p. 643-660, 2019. 
NAGHETTINI, M.; PINTO, E. J. A. Hidrologia estatística. Belo Horizonte: CPRM, 2007.

KENDALL, M. G. Rank correlation measures. London: Charles Griffin, 1975.

NATIONAL WATER AGENCY. Brazilian National Information System on Water Resources. Portal HidroWeb. Disponível em: https://www.snirh.gov.br/hidroweb/. Acesso em 5 mai. 2020.

OBREGÓN, G.; MARENGO, J. A. Caracterização do Clima no Século XX no Brasil: Tendências de Chuvas e Temperaturas Médias e Extremas. Mudanças Climáticas Globais e seus Efeitos sobre a Biodiversidade, Relatório n. 2, CPTEC/INPE, 2007.

PENEREIRO, J. C.; ORLANDO, D. V. Analysis of trends in annual time series of hydrological and climatic data in the Paranaíba river basin between Maranhão and Piauí States, Brazil. Revista Geográfica Acadêmica, v. 7, n. 2, p. 5-21, 2013.

PINTO, E. J. DE A.; AZAMBUJA, A. M. S. DE; FARIAS, J. A. M.; SALGUEIRO, J. P. DE B.; PICKBRENNER, K. (Coords.). Atlas pluviométrico do Brasil: isoietas mensais, isoietas trimestrais, isoietas anuais, meses mais secos, meses mais chuvosos, trimestres mais secos, trimestres mais chuvosos. Brasília: CPRM, 2011. 1 DVD. Escala 1.5:1.000.000. Equipe Executora: Da Costa, Margarida Regueira; Dantas, Carlos Eduardo de Oliveira; De Azambuja, Andressa Macêdo Silva; Do Nascimento, Jean Ricardo da Silva; Dos Santos, André Luis M. Real; Farias, José Alexandre Moreira; Machado, Érica Cristina; Marcuzzo, Francisco Fernando Noronha; Medeiros, Vanesca Sartorelli; Melo, Denise Christina de Rezende; Rodrigues, Paulo de Tarso R.; Weschenfelder, Adriana Burin; Sistema de Informação Geográfica-SIG, versão 2.0, atualizada em novembro/2011; Programa Geologia do Brasil; Levantamento da Geodiversidade. Disponível em: http://www.cprm.gov.br/publique/Hidrologia/Estudos-Hidrologicos-e-Hidrogeologicos/Atlas-

Pluviometrico-do-Brasil-6604.html. Acesso em: 26 abr. 2021.

PIYOOSH, A. K.; GHOSH, S. K. Effect of autocorrelation on temporal trends in rainfall in a valley region at the foothills of Indian Himalayas. Stochastic Environmental Research and Risk Assessment, v. 31, n. 8, p. 2075-2096, 2017.

SANTOS, C. A. et al. Análise Estatística Da Não Estacionariedade De Séries Temporais De Vazão Máxima Anual Diária Na Bacia Hidrográfica Do Rio Pardo. Holos, v. 7, p. 179-193, 2016.

SEN, P. K. Estimates of the Regression Coefficient Based on Kendall's Tau. Journal of the American Statistical Association, v. 63, n. 324, p. 1379-1389, 1968.

SIQUEIRA, B.; NERY, J. T.; MARTINS, G. Variabilidade sazonal da precipitação na bacia do Paraná em território brasileiro. Revista Brasileira de Climatologia, v. 23, p. 45-59, 2018.

QUADROS, L. E. et al. Rainfall trends for the State of Parana: present and future climate. Ambiente e Agua - An Interdisciplinary Journal of Applied Science, v. 14, n. 2, e2258, 2018.

MANDELBROT, N. N.; WALLIS, J. R. Noah, Joseph and Operational Hydrology. Water Resources Research, n. 4, n. 5, p. 909-918, 1968.

STAHL, K. et al. Streamflow trends in Europe: evidence from a dataset of near-natural catchments. Hydrology and Earth System Sciences, v. 14, p. 2367-2382, 2010.

ZUFFO, A. C. O Sol, o motor das variabilidades climáticas. Revista DAE, v. 63, p. 6-24, 2015. 
TAN, X.; GAN, T. Y.; SHAO, D. Effects of persistence and large-scale climate anomalies on trends and change points in extreme precipitation of Canada. Journal of Hydrology, v. 550, p. 453-465, 2017.

TEEGAVARAPU, R. S. V.; NAYAK, A. Evaluation of long-term trends in extreme precipitation: Implications of in-filled historical data use for analysis. Journal of Hydrology, v. 550, p. 616-634, 2017.

THEIL, H. A rank-invariant method of linear and polynomial regression analysis. A Mathematical Sciences, v. 53, p. 386-392, 1950.

ULIANA, E. M. et al. Análise de tendência em séries históricas de vazão e precipitação: uso de teste estatístico não paramétrico. Ambiente e Água - An Interdisciplinary Journal of Applied Science, v. 10, n. 1, p. 445-458, 2015

YANG, Y. et al. A framework for assessing flow regime alterations resulting from the effects of climate change and human disturbance. Hydrological Sciences Journal, v. 63, n. 3, p. 441-456, 2018.

ZANDONADI, L. et al. Changes in precipitation extremes in Brazil (Paraná River Basin). Theoretical and Applied Climatology, v. 123, p. 741-756, 2015.

PETTITT. A. Non-Parametric Approach to the Change-Point Problem. Applied Statistics, v. 28, n. 2, p. 126-135, 1979.

\section{AUTHORSHIP CONTRIBUTIONS}

\section{1 - Bruno Henrique Toná Juliani}

Federal University of Paraná, Msc in Water Resources and Environmental Engineering https://orcid.org/0000-0001-8764-5669 - brunotjuliani@gmail.com

Contributions: Data curation, formal analysis, investigation, software, visualization, writing - original draft.

\section{2 - Cristhiane Michiko Passos Okawa}

State University of Maringá, PhD in Water Resources https://orcid.org/0000-0002-1705-8204 -cmpokawa@uem.br

Contributions: Conceptualization, validation, writing - review \& editing.

\section{3 - Miriam Rita Moro Mine}

Federal University of Paraná, PhD in Water Resources and Environmental Sanitation https://orcid.org/0000-0001-5586-0639-mrmine.dhs@ufpr.br

Contributions: Conceptualization, supervision, project administration.

\section{HOW TO QUOTE THIS ARTICLE}

JULIANI, B. H. T.; OKAWA, C. M. P.; MINE, M. R. M. Changes in precipitation rates over the last 70 years in Eastern Paraná State, Brazil. Ciência e Natura, Santa Maria, v. 43, e15, p. 120, 2021. DOI: https://doi.org/10.5902/2179460X63260. Accessed: Month (Abbreviated) day, year. 